\title{
Patterns of Urban Heat Island Effect in Adelaide: A Mobile Traverse Experiment
}

\author{
Ehsan Sharifi ${ }^{1} \&$ Ali Soltani ${ }^{2}$ \\ ${ }^{1}$ Urban Microclimate Group, School of ITMS, OC1-75, Mawson Lakes Campus, University of South Australia, \\ Australia \\ ${ }^{2}$ Department of Urban Planning, Shiraz University, Shiraz, Iran \\ Correspondence: Ali Soltani, Department of Urban Planning, Shiraz University, Shiraz, Iran. E-mail: \\ soltani@shirazu.ac.ir
}

Received: December 24, 2016

Accepted: February 16, 2017 Online Published: March 10, 2017

doi:10.5539/mas.v11n $4 \mathrm{p} 80$

URL: http://doi.org/10.5539/mas.v11n4p80

\begin{abstract}
Urban structure, hard surfaces and shortage of vegetation cause an artificial temperature increase in cities, known as the urban heat island effect. This paper determines the daily patterns of urban heat in Adelaide, Australia. The near-surface temperature profile of Adelaide was mapped in 60 journeys alongside a straight cross route connecting Adelaide Hills to the West Beach between 26 July and 15 August 2013. Results indicate that the most intense urban-rural temperature differences occurred during midnight in Adelaide. However, the afternoon urban heat had more temperature variation in the urban area. In the late afternoon, the near-surface urban heat fluctuates by $2^{\circ} \mathrm{C}$ within three kilometres and by $1.2^{\circ} \mathrm{C}$ in just one kilometer. Afternoon heat stress can vary based on space configurations and urban surface covers. Afternoon heat stress causes the highest heat load on urban dwellers. A better understanding of daily urban heat variations in cities assists urban policy making and public life management in the context of climate change.
\end{abstract}

Keywords: Urban heat island effect, global warming, Adelaide, mobile traverse, heat stress

\section{Introduction}

Australia is likely to experience $3.8^{\circ} \mathrm{C}$ increase in its surface temperature by 2090 (CSIRO, 2007). Such larg-scale warming will have a severe impact on regional and local climate regimes, natural ecosystems, and human life. In the context of global warming, heat stress can reach up to $10^{\circ} \mathrm{C}$ in urban settings compared to their rural counterparts (Erell, Pearlmutter, \& Williamson, 2011). Natural landscapes in and around cities are increasingly replaced by hard and impermeable surfaces (Girardet, 2008; Harden et al., 2014). Urban structure, hard surfaces and shortage of vegetation cover in cities cause an artificial temperature increase in cities, commonly known as the urban heat island (UHI) effect (Gartland, 2008; Stone, 2012).

Current UHI scholarship includes extensive macro-scale urban heat mapping in cities worldwide. It also covers the effect of urban surface covers on the formation of the UHI effect as a nocturnal phenamenon. However, very limited research is available on daily variations of the urban heat in cities when the UHI effect threatens usability of outdoor public spaces (Kovats \& Hajat, 2008; Nikolopoulou, 2004; Sharifi et al., 2016). In response to substantial excess heat in cities, people increasingly move into air-conditioned buildings to benefit from indoor thermal comfort. Resulted anthropogenic heat generated from indoor air-conditioning causes an ever-increasing outdoor temperature.

In this context, this paper determines daily patterns of urban heat island effect in Adelaide metropolitan area via mobile traverse method. A better understanding of daily urban heat variations in cities assists urban policy making and public life management in the context of climate change.

\section{The Urban Heat Island (UHI) Effect}

Background literature of the UHI effect indicates that such artificial increase of urban temperature occurs because of changes in energy and water budget in the built environment (Erell et al., 2011; Gartland, 2008; Karatasou, Santamouris, \& Geros, 2006; Oke, 2006b). In the early 19th century, Howard's urban heat mapping in London indicates that mean annual temperature (20-years average) in London is $2.5^{\circ} \mathrm{C}$ higher than its countryside $\left(1833\right.$, p. 32) while the peak air temperature variation of $3^{\circ} \mathrm{C}$ is recorded during February 
(mid-winter). Similar urban heat stress has been reported in Paris and Vienna by the 20th century (Gartland, 2008; Stewart, 2011).

Macro-scale urban heat investigations contribute mainly to the understanding of the UHI effect mechanism via comparing city centres and their rural surroundings (Oke, 1987, 1988; Paterson \& Apelt, 1989; Tapper, 1990). Numerous case studies strongly support the relatively higher temperature in highly developed urban areas including city centres (see a few examples in Table 1). However, the accuracy and applicability of many of these case studies are under criticism in more advanced urban climate research by highlighting instrumental and measurement variations (Oke, 2006b; Stewart, 2011).

Gartland (2008, p. 2) enumerates five common characteristics for the UHI effect:

- UHIs are warmer than their rural surroundings

- Urban air temperatures get higher due to human-made modifications of urban surface covers

- The urban-rural temperature differences increase in calm and clear weather (at night time and in winter)

- $\quad$ More development and less greenery correlate to the intensity of UHIs

- $\quad$ UHIs create a dome of warmer air above urban cities

Table 1. Reported magnitude of the UHI effect in selected literature since the $1980 \mathrm{~s}$

\begin{tabular}{lll}
\hline Location & Reported UHI intensity $\left({ }^{\circ} \mathrm{C}\right.$ ) & Reference \\
\hline Calgary, Canada & 10.1 (winter) & (Nkemdirim \& Truch, 1978) \\
Malmo, Sweden & 6 (summer) & (Bärring, Mattsson, \& Lindqvist, 1985) \\
Essen, Germany & 7 (maximum) & (Swaid \& Hoffman, 1990) \\
Shanghai, China & $3-4$ & (Djen, Jingchun, \& Lin, 1994) \\
Singapore & 8.4 (maximum) & (Nichol, 1996) \\
Melbourne, Australia & 4 (maximum) & (Morris \& Simmonds, 2000) \\
Granada, Spain & 6 (winter) & (Montávez, Rodríguez, \& Jiménez, 2000) \\
Athens, Greece & 3.1 (summer) & (Santamouris et al., 2001) \\
London, UK & $1-3$ & (Watkins, Palmer, Kolokotroni, \& Littlefair, 2002) \\
Phoenix, USA & 10 (maximum) & (Hawkins, Brazel, Stefanov, Bigler, \& Saffell, 2004) \\
Hong Kong, China & 8 (maximum) & (Giridharan, Lau, Ganesan, \& Givoni, 2007) \\
Singapore & 5.4 (winter) & (Wong \& Yu, 2008) \\
Phoenix, USA & 0.8 (summer) & (Lee, Lee, \& Wang, 2012) \\
Adelaide, Australia & $3-4$ & (Guan et al., 2013) \\
\hline
\end{tabular}

Heat islands are uneven in their spatial distribution and magnitude (Oke, 2006b; Wong \& Yu, 2008), and can vary based on the space configuration and urban features in smaller scales (Erell et al., 2011). Distribution of nocturnal UHI effect varies from diurnal heat stress. The magnitude of urban-rural temperature differences is usually reported to be higher at night time (Runnalls \& Oke, 2000). As such the UHI effect is frequently known as a night time phenomenon in urban climatology (Arnfield, 2003; Erell et al., 2011; Gartland, 2008; Ichinose, Matsumoto, \& Kataoka, 2008; Oke, 1988, 2006a; Yow, 2007).

UHI literature indicates that the urban-rural temperature differences start to develop during the day under clear sky due to the maximum chance of solar gain (Arnfield, 2003; Ashie, 2008; Erell, 2008; Gartland, 2008; Karatasou, Santamouris, \& Geros, 2006; Oke, 1987, 1988, 2006b; Ryu \& Baik, 2012; Tapper, 1990; Yow, 2007). Calm weather conditions cause the warm air to be withheld in the built environment for an extended time (Gartland, 2008; Morris, Simmonds, \& Plummer, 2001; Oke, 2006b; Wong \& Yu, 2008). Urban structure, surface materials, metabolism and lack of adequate landscape are cited as key contributors to the UHI effect (Gartland, 2008; Oke, 2006b). Due to the heat-trapping urban structure and surface covers, the stored heat remains in the built environment during the night (Erell et al., 2011; Gartland, 2008; Rizwan, Dennis, \& Liu, 2008) and causes the urban areas to have extended heat stress at night.

\subsection{Scales and Metrics of the UHI Effect}

The importance of scale in UHI research has been emerged after the development of remote sensing thermal imagery in the 1980s. Remote sensing has added surface temperature mapping to the conventional air temperature measurement in UHI research (Arnfield, 2003; Gartland, 2008). To date UHI studies are represented 
in three major scales: surface layer (surface material scale), canopy layer (building and public space scale) and boundary layer (city scale) (Arnfield, 2003; Erell et al., 2011; Oke, 1988, 2006b).

\subsubsection{Urban Surface Layer}

The surface layer UHI studies focus on the surface material's immediate heat transfer. The UHI effect is highly dependent on thermal behaviour of surface materials and their exposure to solar radiation. Buildings' envelope surfaces (rooftops and facades) and open spaces' covers have a range of physical and thermal properties (specific heat, material density, mass, albedo, emissivity and thermal diffusivity). They also have a range of exposure time to the sunlight. While any isolated material has a complex heat exchange with its surrounding environment, the combination of surface materials in an urban setting make the system more complex (Erell, 2008; Karatasou, Santamouris, \& Geros, 2006; Yow, 2007). Therefore, a large body of the UHI effect research reflects the surface materials in urban surface layer. The urban surface layer is also known as laminar boundary layer of the built environment. The UHI effect in urban surface layer tends to maximise under a clear sky in the early afternoon (see Figure 1).

\subsubsection{Urban Canopy Layer}

Emitted heat from urban surfaces is mixed through convection and affects the air temperature above the surface layer. At the scale of buildings and public spaces, the urban section limited between the surface layer and the canopy of trees or up to the skyline of buildings is regarded as urban canopy layer (Arnfield, 2003; Erell et al., 2011). The urban canopy layer is also known as the turbulent surface layer in which the thermal characteristic is directly affected by the surface materials heat flux. The urban canopy layer is also highly dependent on the air turbulence patterns in the built environment (Oke, 1987). The geometry of urban canyons (linear open spaces such as streets), the aspect ratio of open spaces (height to width ratio), land cover materials such (asphalt, hard-landscapes, grass cover, water and tree) and wind flow affect the urban heat accumulation in the canopy layer. The UHI effect in urban canopy layer tends to be maximum in calm and clear weather especially in the late afternoon and early night (Johnson et al., 1991).

\subsubsection{Urban Boundary Layer}

Emitted heat from urban surface layer mixes via air turbulence in urban canopy layer and above. Resulted air mixture shapes a dome of warm air over the urban areas which is referred to as the urban boundary layer. The formation of warm air dome over built-up areas is because of the blending effect of local air above the canopy layer (Oke, 1987; Tapper, 1990; Thatcher \& Hurley, 2012). The height of such a warm air dome can reach up to 1500 meters above the urban surfaces at midnight while it is normally around 500 meters in rural vicinities in the early morning (Harman \& Belcher, 2006; Morris \& Simmonds, 2000; Oke, 2006b; Souch \& Grimmond, 2006).

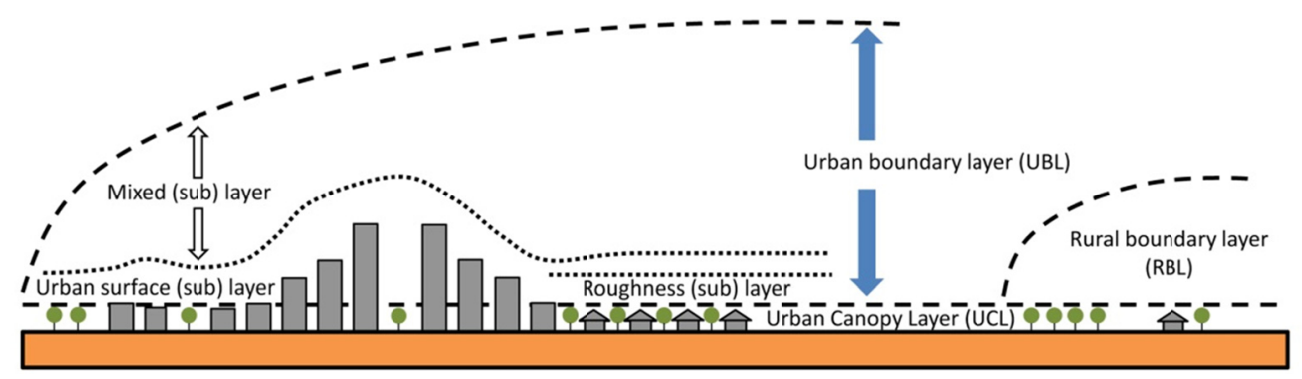

Figure 1. The UHI effect is identifiable in the urban skin layer, urban canopy layer and urban boundary layer, each with specific characteristics, contributing elements and potential sub-layers. Redrawn and modified based on (Sailor, 2015, p. 272)

The boundary layer includes three sub-layers: immediately above uniform land cover features with tall elements, there is an interacting up-down trend in warm air elevation, matching with the physical roughness elements, which is referred to as roughness sub-layer. This roughness sub-layer is being moderated by local wind flow at an elevation of four to five times that of the average of buildings. The second sub-layer is referred to as inertial surface sub-layer. The air temperature in the inertial surface sub-layer is not affected by individual surface materials, but it is affected by the urban surface composition and land cover typologies. The third sub-layer of the urban boundary layer is mixed sub-layer, which is formed above the inertial surface sub-layer. In the mixed layer, the thermal characteristics of the air are no longer the direct result of the materials bellow, but the mixture of thermal characteristics of inertial surface (sub) layers and local wind flows (Oke, 1987; Sailor, 2015) (see 
Figure 2 for a schematic illustration of UHI layers). The urban boundary layer tends to maximise during the midnight when the hotter air elevates to higher altitudes.

As the scale increases, the UHI effect is moderated by air turbulence through convection. Thus, the UHI effect variability decreases with an increase in spatial scale (Erell et al., 2011; Priyadarsini, 2009). It is likely to detect more temperature differences between North and South sides of a building facade than two different urban features in a precinct (streetscape versus park).

Table 2. Scale and layers in the UHI research. As the scale increases, the UHI effect gets moderated by air turbulence.

\begin{tabular}{|c|c|c|c|c|}
\hline Scale & layer & $\begin{array}{l}\text { Focused } \\
\text { temperature }\end{array}$ & Focused elements & $\begin{array}{l}\text { Dimension range } \\
\text { (approximate) }\end{array}$ \\
\hline Micro & Skin layer & $\begin{array}{l}\text { Surface } \\
\text { temperature }\end{array}$ & $\begin{array}{l}\text { Open Space skin } \\
\text { Building rooftops } \\
\text { Building facades }\end{array}$ & $1-10 \mathrm{~m}$ \\
\hline Micro-local & Canopy layer & Air temperature & $\begin{array}{l}\text { Open spaces between buildings } \\
\text { Public spaces } \\
\text { streetscapes } \\
\text { Land cover feature classes } \\
\text { Urban precincts }\end{array}$ & $10-10^{3} \mathrm{~m}$ \\
\hline Local & $\begin{array}{l}\text { Roughness (sub) } \\
\text { layer }\end{array}$ & Air temperature & $\begin{array}{l}\text { Warm waves of air over tall elements } \\
\text { of a uniform surface }\end{array}$ & $10^{2}-10^{3} \mathrm{~m}$ \\
\hline Local & $\begin{array}{l}\text { Inertial surface } \\
\text { (sub) layer }\end{array}$ & Air temperature & $\begin{array}{l}\text { Blended warm air over uniform } \\
\text { surfaces }\end{array}$ & $10^{2}-10^{3} \mathrm{~m}$ \\
\hline Macro & $\begin{array}{l}\text { Mixed (sub) } \\
\text { layer }\end{array}$ & $\begin{array}{l}\text { Surface and air } \\
\text { temperature }\end{array}$ & $\begin{array}{l}\text { Land use classes } \\
\text { Urban regions }\end{array}$ & $10^{3}-10^{5} \mathrm{~m}$ \\
\hline
\end{tabular}

The UHI vertical layers are not static and can vary in depth in daily cycle. Figure 2 shows that the depth of skin layer can be very low (a few centimetres due to the high thermal resistance of the air) and is highly dependent on the direct and diffuse solar radiation and materials' thermal specifications. The depth of the canopy layer is measured via the physical elements of the built environment not the volume of warm air. However, the intensity of air temperature in canopy layer reaches its maximum in the late afternoon, when the urban canopy is being exposed to the solar radiation for many hours. The urban boundary layer, however, reaches its highest volume during the evening, when the warm air elevated through the lower atmosphere and forms the dome of warm air all over the urban area (Gartland, 2008; Oke, 1987; Sailor, 2015). The non-urban boundary layer waxes and wanes diurnally, with its maximum at the time of maximum surface heating.

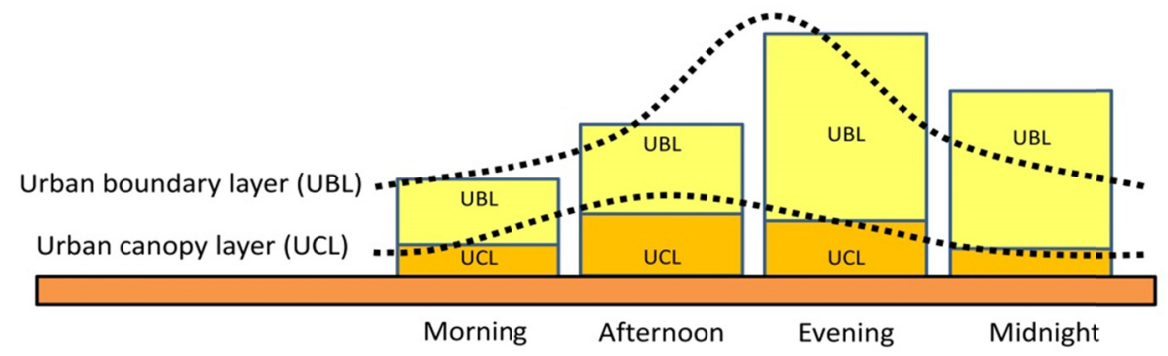

Figure 2. Schematic daily variations in urban climate layer and urban boundary layer

\section{Methods}

Despite the consensus existence of the UHI effect in urban areas, a wide range of values is reported for UHI magnitude. Such variation among reported UHI effect exists partially due to a variety of measurement methods and scales (Stewart, 2011). To date, the UHI scholarship uses five methods to measure the UHI effect including fixed stations, mobile traverse, remote sensing, vertical sensing and energy balance (Gartland, 2008). As Table 3 reveals, each measurement method may reveal different UHI intensities, showing that surface temperature remote sensing tends to indicate higher UHI intensity compared with long-term and air temperature 
measurements.

Table 3. The magnitude of the UHI effect varies based on methods of data collection and type. Developed based on (Rizwan et al., 2008, p. 123).

\begin{tabular}{|c|c|c|c|c|c|c|}
\hline & \multicolumn{3}{|l|}{ Method 1} & \multicolumn{3}{|l|}{ Method 2} \\
\hline & $\begin{array}{l}\text { Data } \\
\text { collectionme } \\
\text { method }\end{array}$ & Data type & $\begin{array}{l}\text { Reported } \\
\text { UHI effect } \\
\left({ }^{\circ} \mathrm{C}\right)\end{array}$ & $\begin{array}{l}\text { Data } \\
\text { collection } \\
\text { method }\end{array}$ & Data type & $\begin{array}{l}\text { Reported } \\
\text { UHI effect } \\
\left({ }^{\circ} \mathrm{C}\right)\end{array}$ \\
\hline $\begin{array}{l}\text { Tokyo, } \\
\text { Japan }\end{array}$ & $\begin{array}{l}\text { Mobile } \\
\text { traverse }\end{array}$ & $\begin{array}{l}\text { Surface } \\
\text { temperature }\end{array}$ & 8.0 & $\begin{array}{l}\text { Satellite } \\
\text { data }\end{array}$ & $\begin{array}{l}\text { Surface } \\
\text { temperature }\end{array}$ & 12.0 \\
\hline $\begin{array}{l}\text { Atlanta, } \\
\text { USA }\end{array}$ & Modelled & $\begin{array}{l}\text { Surface } \\
\text { temperature }\end{array}$ & 1.2 & Modelled & $\begin{array}{l}\text { Air } \\
\text { temperature }\end{array}$ & 0.6 \\
\hline $\begin{array}{l}\text { Seoul, } \\
\text { Korea }\end{array}$ & $\begin{array}{l}\text { Weather } \\
\text { station }\end{array}$ & $\begin{array}{l}\text { Air } \\
\text { temperature }\end{array}$ & 3.4 & $\begin{array}{l}\text { Satellite } \\
\text { data }\end{array}$ & $\begin{array}{l}\text { Surface } \\
\text { temperature }\end{array}$ & 8.0 \\
\hline
\end{tabular}

The magnitude of the UHI effect tends to be higher during calm and sunny weather in winter (Gartland, 2008). To investigate the variations in near-surface air temperature in a city with temperate climate, an urban heat measurement was done in Adelaide in winter 2013. The urban near-surface temperature profile of Adelaide's metropolitan area was measured alongside a straight route connecting Adelaide Hills and the West Beach. Total 60 mobile traverse profiles were recorded during 12 sunny and partly cloudy days between 26 July and 15 August 2013 (see Figure 3 for the traverse path). Each journey last 30-35 minutes depending on the local traffic.

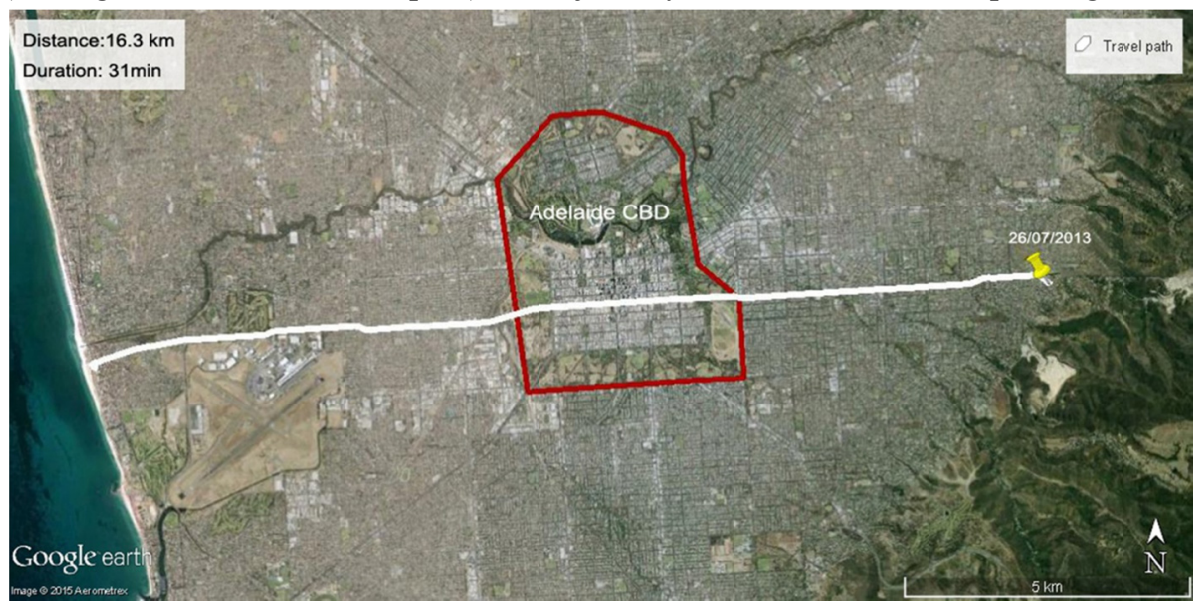

Figure 3. Mobile traverse path to measure UHI effect in Adelaide in winter 2013 (Map data: AEROmetrex, 2015; Google Earth, 2015)

\subsection{The Mobile Traverse Method}

Because of the limited availability of fixed stations in appropriate locations and the high cost and logistics requirements for temporary fixed stations, the mobile traverse method is an economical and fast way to draw the UHI profile of a city (Gartland, 2008; Yow, 2007). In mobile traverse method, a portable weather station measures air temperature and in some cases relative humidity when moving through predetermined paths. Mode of transportation can vary based on the scale and accuracy of investigation. Macro-scale studies use public transport or cars as the mean of transportation (Saitoh, Shimada, \& Hoshi, 1996; Iain Douglas Stewart, 2000; Yamashita, 1996), whereas micro-scale investigators use walking or cycling for moving through urban paths (Spronken-Smith \& Oke, 1998).

In both situations, the duration of each experiment is a critical factor since the weather conditions might change during the experiment. A majority of mobile traverse measurements last for a maximum of an hour to decrease the effect of weather variations (Gartland, 2008). However, even within an hour, urban microclimates might noticeably change. In this experiment the near-surface air temperature was measured during journeies in the early afternoon (14:00-14:35), mid-afternoon (16:10-16:45), late afternoon (18:00-18:35), early night (21:0021:35) and midnight (22:45-23:20). Recorded data were moderated against official weather data of Australian 
Bureau of Meteorology at Roseworthy station (ID: 023122). Roseworthy station is located 56km North of Adelaide CBD. Therefore, its data were used to analyse the patterns of urban heat in Adelaide metropolitan. Weather data were used to correct the recorded temperatures during the mobile traverse journeys.

$$
\mathrm{T}_{\text {corrected }}=\mathrm{T}_{\text {recorded }}-\Delta \mathrm{T}_{\text {local weather variation }}
$$

The near-surface temperature was measured via an EXTECH RHT10 hygrometer data logger with magnetic stand. The data logger unit was installed $1200 \mathrm{~mm}$ above the ground surface on a 200mm pole on the left side of a passenger car, and was covered by a white paper tube to prevent the rapid effect of solar radiation. Dry-bulb temperature and relative humidity were recorded every 10 seconds and averaged every minute. Each journey of $16.3 \mathrm{~km}$ took 30-35 minutes to complete depending on the local traffic. Duplicated data were cleaned afterwards to remove inevitable traffic light stoppages. Recorded temperatures were corrected based on temperature changes during the journeys measured at Roseworthy station (see Figure 3).

The other limitation of the mobile traverse method is related to the temperature sensors. The mobile travel weather sensor is commonly fixed on a moving object such as a car or a bicycle. When the sensor is adjusted at the height of 1200-1500mm above the ground, the measurement can be influenced by rough surfaces such as asphalt or paving. Therefore, the sensor is usually fixed on the moving vehicle at the height of $2000 \mathrm{~m}$. Also, to get a trusted measurement, the sensor needs to be held in each data recording locations for a few minutes, which increases the duration of the UHI measurement. Local traffic can also influence the measurement timespan in the mobile traveller method.

\section{Results}

Journeys began at the eastern end of Kensington Road in Adelaide Hills, and continued in a straight line to Wakefield Road and Grote Street in the city centre of Adelaide, and finished at the western end of Sir Donald Bradman Drive at Adelaide's West Beach. Recorded near-surface air temperature along the travel path are shown in Figure 4.

Assessment of recorded data against weather data of the Australian Bureau of Meteorology's Roseworthy station indicates that the central part of Adelaide CBD experienced higher temperature differences compared to suburban areas during all measurements (see Figure 4). The near-surface urban heat has an even curved shape with a peak value of $5.9{ }^{\circ} \mathrm{C}$ in its centre during midnight (compared to Roseworthy station data). Therefore, the Adelaide metropolitan area represents an urban heat island, in which stored heat during the afternoon is discharged to the atmosphere with a delay of up to six hours.

The urban heat profile during the early night has more thermal fluctuation along the travel path, especially at the eastern and western boundaries of the city centre. Such thermal fluctuations resulted in up to $1{ }^{\circ} \mathrm{C}$ near-surface temperature differences in very short distances of less than one kilometre from the city centre. More fluctuation is visible in early and late afternoon urban heat profiles when up to $2^{\circ} \mathrm{C}$ temperature differences are recorded in CBD vicinities.

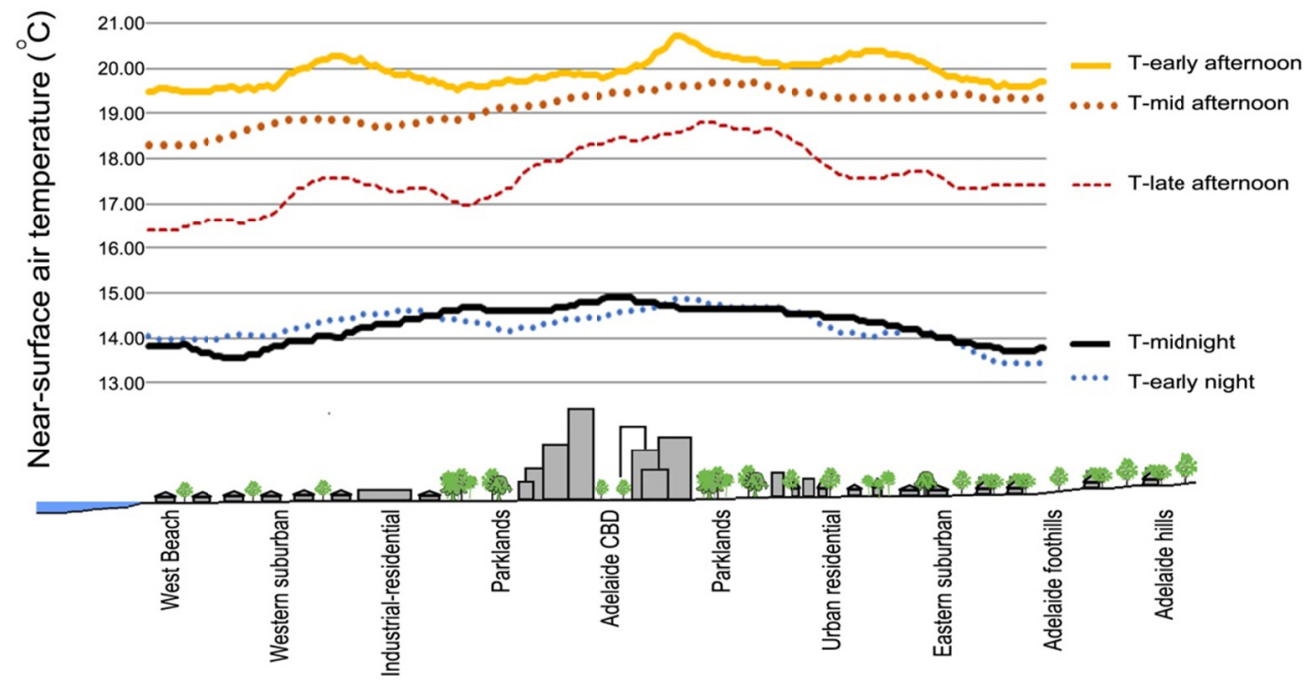

Figure 4. Averaged near-surface temperature profile of Adelaide measured between 26 July and 15 August 2013 via mobile traverse method during five 31-minute journeys $(\mathrm{N}=60)$ 
As Figure 5 and Table 4 show, the near-surface urban heat in Adelaide (compared to Roseworthy station) alters from a minimum of $1.5^{\circ} \mathrm{C}$ in the early afternoon to a maximum of $5.9^{\circ} \mathrm{C}$ in midnight during a typical winter day. Heat load accumulates during the afternoon in the built environment and is discharged to the atmosphere with delay during the night. However, such heat accumulation is not seen in the urban profile during the afternoon, when open spaces are exposed to the solar radiation. This shows the contribution of stored heat release and reduced longwave cooling in urban heat in Adelaide.

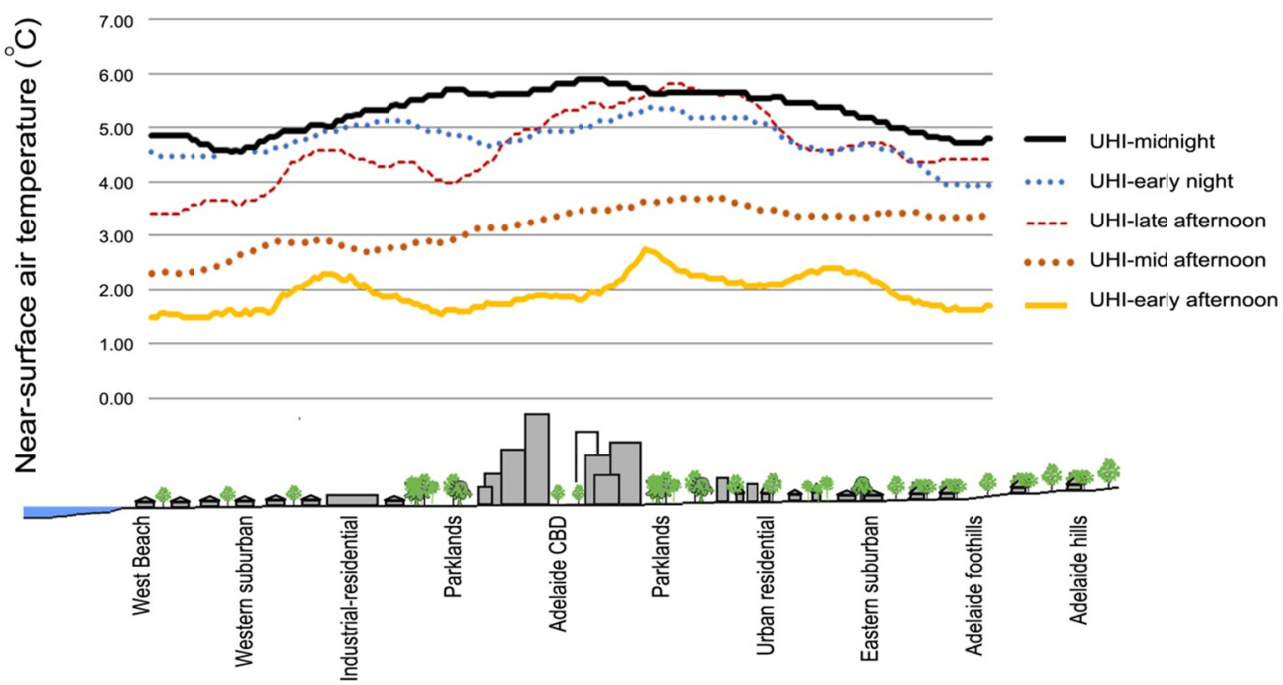

Figure 5. Relative neat-surface urban heat island effect of Adelaide metropolitan (east-west profile) between 26 July and 15 August $2013(\mathrm{~N}=60)$

In the late afternoon, the near-surface urban heat fluctuates by $2{ }^{\circ} \mathrm{C}$ in three kilometres and by $1.2^{\circ} \mathrm{C}$ in just one kilometre. Guan et al. (2013) argue that such variations occur mainly due to the existence of parklands around the Adelaide CBD, which has considerably higher urban greenery compared to both the CBD and most suburban areas. However, Guan et al. (2013) do not provide any explanation for small-scale thermal variations in the CBD and suburban areas. Meanwhile, as Figure 5 also illustrates that the cooling effect of urban greenery is more significant during the late afternoon (immediately after sunset).

Table 4. Descriptive analysis of averaged urban heat patterns in Adelaide metropolitan area, measured between 26 July and 15 August 2013 with mobile traverse method (east-west path; $\mathrm{N}=60$ ).

\begin{tabular}{llllll}
\hline & $\begin{array}{l}\text { Early afternoon } \\
\left({ }^{\circ} \mathrm{C}\right)\end{array}$ & $\begin{array}{l}\text { Mid-afternoon } \\
\left({ }^{\circ} \mathrm{C}\right)\end{array}$ & $\begin{array}{l}\text { Late } \\
\left({ }^{\circ} \mathrm{C}\right)\end{array}$ & $\begin{array}{l}\text { Early night } \\
\left({ }^{\circ} \mathrm{C}\right)\end{array}$ & $\begin{array}{c}\text { Midnight } \\
\left({ }^{\circ} \mathrm{C}\right)\end{array}$ \\
\hline Mean & 1.93 & 3.15 & 4.62 & 4.78 & 5.30 \\
Standard Error & 0.02 & 0.03 & 0.05 & 0.03 & 0.03 \\
Median & 1.88 & 3.34 & 4.58 & 4.83 & 5.41 \\
Standard & 0.31 & 0.40 & 0.66 & 0.36 & 0.40 \\
Deviation & & & & & 0.13 \\
Sample Variance & 0.09 & 0.16 & 0.44 & -0.60 & -0.33 \\
Skewness & 0.38 & -0.62 & 0.08 & 3.93 & 4.56 \\
Minimum UHI & 1.47 & 2.30 & 3.40 & 5.37 & 5.90 \\
Maximum UHI & 2.73 & 3.75 & 5.81 & & \\
\hline
\end{tabular}

\section{Discussion}

Heat islands are uneven in their spatial distribution and magnitude (Oke, 2006b; Wong \& Yu, 2008), and can vary based on the space configuration and urban features in smaller scales (Erell et al., 2011). Although the nocturnal UHI effect is concentrated in highly urbanised areas such as city centres, the daytime urban heat follows different patterns, and it may have very high magnitudes in some urban settings, lower intensity in other areas, and in some cases negative values in park cool islands. Adelaide has a unique urban structure with a CBD 
surrounded by parklands and outer suburban areas. Recent research on the urban heat in Adelaide suggests that the existence of parklands is effectively mitigate the urban heat of the CBD (Clay et al., 2016; Guan et al., 2013).

The midnight urban heat in Adelaide has the most intense temperature differences (urban-airport) in Adelaide (refer to the higher values of mean, minimum, and maximum in Table 4). However, the afternoon urban heat has more temperature variance (point-to-point variation), especially during the late afternoon (refer to higher values of sample variance, standard deviation, and skewness in Table 4).

The averaged near-surface urban heat was the highest in Adelaide during the midnight traverses. However, the $6^{\circ} \mathrm{C}$ higher temperature during winter nights, when the suburban temperature may be as low as $9^{\circ} \mathrm{C}$, is not a threat (in fact, it could be an advantage). Nevertheless, the midnight urban heat could be a threat during summer heatwaves with midnight minimum temperatures of more than $30^{\circ} \mathrm{C}$. The afternoon urban heat may be even more harmful during summer when solar radiation is more intense, days are longer, and the temperature profile is considerably higher than winter. The $2.4^{\circ} \mathrm{C}$ temperature variations in the late afternoon could make an acceptable outdoor thermal environment uncomfortable to attend, or push the boundaries of thermal discomfort towards stronger heat stress (the pilot study had been done in winter due to the higher probability of urban heat).

The near-surface urban heat measurement in Adelaide indicate that:

- $\quad$ Due to urban geometry, some urban spaces store more heat compared to others. Such heat load variations may occur over walking distances (500-1000 m) in urban spaces with different spatial configurations.

- The urban heat is lower during the afternoon compared to midnight. However, near-surface temperature fluctuation is higher during the afternoon.

- The afternoon urban heat could be more harmful to humans during summer, although it provides better thermal comfort conditions during the winter.

\section{Policy implication}

This mobile traverse urban heat study of Adelaide supports the argument of heat stress variability in the built environment during daily cycles and within short distances. The UHI measurements are commonly performed during the night - when the urban-rural temperature differences are at their maximum. Thus, they fall short in addressing the issue of excess heat stress on human participants. However, having thermally comfortable urban microclimates is a fundamental characteristic of healthy and vibrant public spaces (Gehl, 2010, 2011). Therefore, urban planning professionals and decision makers are required to consider diurnal heat stress alongside nocturnal urban heat islands in planning healthy cities.

Results of this study suggest that the maximum urban heat stress occurs during the afternoon when both overall temperature and daily urban heat are at their peak. Such daily heat stress in canopy layer decreases in urban parklands and near water bodies. However, daily heat stress peaks in hard-landscapes urban settings. Thus, urban greenery and surface water can assist achieving more liveable and healthy urban environments.

\section{Conclusions}

Diurnal heat stress varies in the built environment during daily cycles and within short distances. The midnight urban heat in Adelaide had the most intense urban-rural temperature differences in winter. However, the afternoon urban heat has more temperature variation (point-to-point variation), especially during the late afternoon. The highest temperatures were recorded during the early afternoon (summer urban heat might be different). If similar patterns occur during summer heatwaves, the afternoon heat stress can cause significant outdoor thermal discomfort. The highest urban heat was recorded in the western industrial-residential suburbs that have less vegetation and more hard surfaces.

Diurnal heat stress in canopy layer decreases in urban parklands and near water bodies. However, daily heat stress peaks in hard-landscapes urban settings. Thus, urban greenery and surface water can assist achieving more liveable and healthy urban environments. A better understanding of daily urban heat variations in cities assists urban policy making and public life management in the context of climate change.

\section{Acknowledgments}

This paper draws on the work of the authors at the University of South Australia. It is a part of a research project on Urban Microclimates of Sydney, Melbourne and Adelaide - supported by the CRC for Low Carbon Living and a range of industry and government stakeholders including the City of Adelaide.

\section{References}

AEROmetrex (Cartographer). (2015). 
Arnfield, A. J. (2003). Two Decades of Urban Climate Research: a Review of Turbulence, Exchanges of Energy and Water, and The Urban Heat Island. International Journal of Climatology, 23(1), 1-26. https://doi.org/10.1002/joc.859

Ashie, Y. (2008). Management of Urban Heat Environment. In K. Hanaki (Ed.), Urban Environmental Management and Technology (pp. 215-238). Tokyo: Springer. https://doi.org/10.1007/978-4-431-78397-8_12

Bärring, L., Mattsson, J. O., \& Lindqvist, S. (1985). Canyon Geometry, Street Temperatures and Urban Heat Island in Malmö, Sweden. Journal of Climatology, 5(4), 433-444. https://doi.org/10.1002/joc.3370050410

Clay, R., Guan, H., Wild, N., Bennett, J., Vinodkumar, \& Ewenz, C. (2016). Urban Heat Island traverses in the City of Adelaide, South Australia. Urban Climate, 17, 89-101. https://doi.org/10.1016/j.uclim.2016.06.001

CSIRO. (2007). Climate Change in Australia: Technical Report. Aspendale VIC: CSIRO and Australian Bureau of Meteorology.

Djen, C. S., Jingchun, Z., \& Lin, W. (1994). Solar Radiation and Surface Temperature in Shanghai City and Their Relation to Urban Heat Island Intensity. Atmospheric Environment, 28(12), 2119-2127. https://doi.org/10.1016/1352-2310(94)90478-2

Erell, E. (2008). The Application of Urban Climate Research in the Design of Cities. Advances in Building Energy Research, 2(1), 95-121. https://doi.org/10.3763/aber.2008.0204

Erell, E., Pearlmutter, D., \& Williamson, T. (2011). Urban Microclimate: Designing the Spaces between Buildings. London: Earthscan.

Gartland, L. (2008). Heat Islands: Understanding and Mitigating Heat in Urban Areas. Washington, DC: Earthscan.

Gehl, J. (2010). Cities for People. Washington, DC: Island Press.

Gehl, J. (2011). Public Spaces and Public Life Survey: City of Adelaide 2011. Adelaide: Adelaide City Council.

Girardet, H. (2008). Cities People Planet: Liveable Cities for a Sustainable World. Chichester: John Wiley \& Sons.

Giridharan, R., Lau, S. S. Y., Ganesan, S., \& Givoni, B. (2007). Urban Design Factors Influencing Heat Island Intensity in High-Rise High-Density Environments of Hong Kong. Building and Environment, 42(10), 3669-3684. https://doi.org/10.1016/j.buildenv.2006.09.011

Google Earth (Cartographer). (2015).

Guan, H., Bennett, J., Ewenz, C., Benger, S., Vinodkumar, Zhu, S., Soebarto, V. (2013). Characterisation, Interpretation and Implications of the Adelaide Urban Heat Island. Adelaide: Flinders University.

Harden, C., Chin, A., English, M., Fu, R., Galvin, K., Gerlak, A., Wohl, E. (2014). Understanding HumanLandscape Interactions in the "Anthropocene". Environmental Management, 53(1), 4-13. https://doi.org/10.1007/s00267-013-0082-0

Harman, I. N., \& Belcher, S. E. (2006). The Surface Energy Balance and Boundary Layer over Urban Street Canyons. Quarterly Journal of the Royal Meteorological Society, 132(621), 2749-2768. https://doi.org/10.1256/qj.05.185

Hawkins, T. W., Brazel, A. J., Stefanov, W. L., Bigler, W., \& Saffell, E. M. (2004). The Role of Rural Variability in Urban Heat Island Determination for Phoenix, Arizona. Journal of Applied Meteorology, 43(3), 476-486. https://doi.org/10.1175/1520-0450(2004)043<0476:TRORVI >2.0.CO;2

Howard, L. (1833). The Climate of London. London: Reprinted 2012, International Assocciation for Urban Climate.

Ichinose, T., Matsumoto, F., \& Kataoka, K. (2008). Counteracting Urban Heat Islands in Japan. In D. Peter (Ed.), Urban Energy Transition: From Fussil Fuels to Renewable Power (pp. 365-380). Amsterdam: Elsevier. https://doi.org/10.1016/B978-0-08-045341-5.00015-3

Johnson, G. T., Oke, T. R., Lyons, T. J., Steyn, D. G., Watson, I. D., \& Voogt, J. A. (1991). Simulation of Surface Urban Heat Islands Under 'Ideal' Conditions at Night Part 1: Theory and Tests Against Field Data. Boundary-Layer Meteorology, 56(3), 275-294. https://doi.org/10.1007/BF00120424

Karatasou, S., Santamouris, M., \& Geros, V. (2006). Urban Building Climatology. In M. Santamouris \& V. Geros 
(Eds.), Environmental Design of Urban Buildings: An Integrated Approach. Sterling: Earthscan.

Kovats, R. S., \& Hajat, S. (2008). Heat Stress and Public Health: a Critical Review. Annual review of public health, 29(1), 41-55. https://doi.org/10.1146/annurev.publhealth.29.020907.090843

Lee, T. W., Lee, J. Y., \& Wang, Z.-H. (2012). Scaling of the Urban Heat Island Intensity Using Time-Dependent Energy Balance. Urban Climate, 2(0), 16-24. https://doi.org/10.1016/j.uclim.2012.10.005

Montávez, J. P., Rodríguez, A., \& Jiménez, J. I. (2000). A Study of the Urban Heat Island of Granada. $\begin{array}{llll}\text { International Journal of } & \text { Climatology, } & \text { 20(8), }\end{array}$ https://doi.org/10.1002/1097-0088(20000630)20:8<899::AID-JOC433>3.0.CO;2-I

Morris, C. J. G., \& Simmonds, I. (2000). Associations between Varying Magnitudes of the Urban Heat Island and the Synoptic Climatology in Melbourne, Australia. International Journal of Climatology, 20(15), 1931-1954. https://doi.org/10.1002/1097-0088(200012)20:15<1931::AID-JOC578>3.0.CO;2-D

Morris, C. J. G., Simmonds, I., \& Plummer, N. (2001). Quantification of the Influences of Wind and Cloud on the Nocturnal Urban Heat Island of a Large City. Journal of Applied Meteorology, 40(2), 169-182. https://doi.org/10.1175/1520-0450(2001)040<0169:QOTIOW>2.0.CO;2

Nichol, J. E. (1996). High-Resolution Surface Temperature Patterns Related to Urban Morphology in a Tropical City: A Satellite-Based Study. Journal of Applied Meteorology, 35(1), $135-146$. https://doi.org/10.1175/1520-0450(1996)035<0135:HRSTPR >2.0.CO;2

Nikolopoulou, M. (2004). Outdoor Comfort. In K. Steemers \& M. A. Steane (Eds.), Environmental diversity in architecture (pp. 101-119). London: Spon (E\&F).

Nkemdirim, L. C., \& Truch, P. (1978). Variability of Temperature Fields in Calgary, Alberta. Atmospheric Environment, 12(4), 809-822. https://doi.org/10.1016/0004-6981(78)90018-5

Oke, T. R. (1987). Boundary Layer Climates (Second edition ed.). New York: Wiley.

Oke, T. R. (1988). The Urban Energy Balance. Progress in Physical Geography, 12(4), $471-508$. https://doi.org/10.1177/030913338801200401

Oke, T. R. (2006a). Initial Guidance to Obtain Representative Meteorological Observations at Urban Sites: Instruments and Observing Methods. IOM Report No. 81. Canada: World Meteorological Organization.

Oke, T. R. (2006b). Towards Better Scientific Communication in Urban Climate. Theoretical and Applied Climatology, 84(1), 179-190. https://doi.org/10.1007/s00704-005-0153-0

Paterson, D. A., \& Apelt, C. J. (1989). Simulation of Wind Flow around 3-Dimensional Buildings. Building and Environment, 24(1), 39-50. https://doi.org/10.1016/0360-1323(89)90015-2

Priyadarsini, R. (2009). Urban Heat Island and its Impact on Building Energy Consumption. Advances in Building Energy Research, 3(1), 261-261. https://doi.org/10.3763/aber.2009.0310

Rizwan, A., Dennis, L., \& Liu, C. (2008). A Review on the Generation, Determination and Mitigation of Urban Heat Island. Journal of Environmental Sciences, $20(1), \quad 120-128$. https://doi.org/10.1016/s1001-0742(08)60019-4

Runnalls, K. E., \& Oke, T. R. (2000). Dynamics and Controls of The Near-surface Heat Island of Vancouver, British Columbia. Physical Geography, 21(4), 283-304.

Ryu, Y. H., \& Baik, J. J. (2012). Quantitative Analysis of Factors Contributing to Urban Heat Island Intensity. Journal of Applied Meteorology and Climatology, 51(5), https://doi.org/10.1175/JAMC-D-11-098.1

Sailor, D. J. (2015). A Holistic View of the Effect of Urban Heat Island Mitigation. In S. Lehmann (Ed.), Low Carbon Cities (pp. 270-281). New York: Routledge.

Saitoh, T. S., Shimada, T., \& Hoshi, H. (1996). Modeling and Simulation of the Tokyo Urban Heat Island. Atmospheric Environment, 30(20), 3431-3442. https://doi.org/10.1016/1352-2310(95)00489-0

Santamouris, M., Papanikolaou, N., Livada, I., Koronakis, I., Georgakis, C., Argiriou, A., \& Assimakopoulos, D. N. (2001). On the Impact of Urban Climate on the Energy Consumption of Buildings. Solar Energy, 70(3), 201-216. https://doi.org/10.1016/S0038-092X(00)00095-5

Sharifi, E., Sivam, A., \& Boland, J. (2016). Resilience to Heat in Public Space: A Case Study of Adelaide, South Australia. Journal of Environmental Planning and Management, 59(10), 1833-1854. 
http://dx.doi.org/10.1080/09640568.2015.1091294

Souch, C., \& Grimmond, S. (2006). Applied Climatology: Urban Climate. Progress in Physical Geography, 30(2), 270-279. https://doi.org/10.1191/0309133306pp484pr

Spronken-Smith, R. A., \& Oke, T. R. (1998). The Thermal Regime of Urban Parks in Two Cities With Different Summer Climates. International Journal of Remote Sensing, 19(11), 2085-2104. https://doi.org/10.1080/014311698214884

Stewart, I. D. (2000). Influence of Meteorological Conditions on the Intensity and Form of the Urban Heat Island Effect in Regina. Canadian Geographer / Le Géographe canadien, 44(3), 271-285. https://doi.org/10.1111/j.1541-0064.2000.tb00709.x

Stewart, I. D. (2011). A Systematic Review and Scientific Critique of Methodology in Modern Urban Heat Island Literature. International Journal of Climatology, 31(2), 200-217. https://doi.org/10.1002/joc.2141

Stone, B. (2012). CITY and the Coming Climate: Climate Change in the Places we Live. New York: Cambridge University Press.

Swaid, H., \& Hoffman, M. E. (1990). Climatic Impacts of Urban Design Features for High and Mid-Latitude Cities. Energy and Buildings, 14(4), 325-336. https://doi.org/10.1016/0378-7788(90)90095-Z

Tapper, N. J. (1990). Urban Influences on Boundary-Layer Temperature and Humidity - Results from Christchurch, New-Zealand. Atmospheric Environment Part B-Urban Atmosphere, 24(1), 19-27. https://doi.org/10.1016/0957-1272(90)90005-F

Thatcher, M., \& Hurley, P. (2012). Simulating Australian Urban Climate in a Mesoscale Atmospheric Numerical Model. Boundary-Layer Meteorology, 142(1), 149-175. https://doi.org/10.1007/s10546-011-9663-8

Watkins, R., Palmer, J., Kolokotroni, M., \& Littlefair, P. (2002). The London Heat Island: Results from Summertime Monitoring. Building Services Engineering Research and Technology, 23(2), 97-106. https://doi.org/10.1191/0143624402bt031oa

Wong, N. H., \& Yu, C. (2008). Tropical Urban Heat Islands: Climate, Buildings and Greenery. New York: Taylor $\&$ Francis

Yamashita, S. (1996). Detailed Structure of Heat Island Phenomena from Moving Observations from Electric Tram-cars in Metropolitan Tokyo. Atmospheric Environment, 30(3), 429-435. https://doi.org/10.1016/1352-2310(95)00010-0

Yow, D. M. (2007). Urban Heat Islands: Observations, Impacts, and Adaptation. Geography Compass, 1(6), 1227-1251. https://doi.org/10.1111/j.1749-8198.2007.00063.x

\section{Copyrights}

Copyright for this article is retained by the author(s), with first publication rights granted to the journal.

This is an open-access article distributed under the terms and conditions of the Creative Commons Attribution license (http://creativecommons.org/licenses/by/4.0/). 